\title{
Asthma and employment in young adults
}

\author{
Bonnie Sibbald, H Ross Anderson, S McGuigan
}

\begin{abstract}
Background Little is known about the effect of asthma on employment. The relation between employment history at the age of 23 years and a history of asthma or wheeze was investigated in a controlled prospective study using data collected in the National Child Development Study, a longitudinal survey of all children born in the United Kingdom in one week in March 1958.

Methods Information about subjects' medical condition was collected at four ages $(7,11,16$, and 23 years) for the original cohort of 17319 births. At 23 years information about employment and education was obtained for 12534 subjects $(72 \%)$, of whom $460(4 \%)$ had current asthma or wheeze, $2758(22 \%)$ had past asthma or wheeze, and $5161(41 \%)$ had never had asthma or wheeze. The remaining subjects could not be classified accurately.
\end{abstract}

Results The risk of unemployment was higher in subjects with a current history of asthma or wheeze (odds ratio 1.32, 95\% confidence interval (CI) 1.09-1.61) or a past history of asthma or wheeze (odds ratio $1 \cdot 54,95 \% \mathrm{CI} 1 \cdot 27-1 \cdot 85$ ) than in those with no such history, after subjects' sex, region of birth, maximum educational qualification, and father's social class had been controlled for. Current and past asthma or wheezing illness predicted a worse employment history in terms of most of the outcomes examined, including mean percentage of months employed since leaving school, mean number of months in current full time job, mean percentage of months unemployed since leaving school, likelihood of being out of the labour force owing to long term illness, and the proportion attaining social groups 1-3. The differences from those who had never had asthma or a wheezing illness were, however, small and generally non-significant.

Conclusion Asthma has only a small adverse effect on employment in young adults.

The effects of asthma on employment in young adults are unknown but could be considerable. Prospective employers may find people with asthma less attractive to hire because they fear that they will be absent more often, or that past asthma may have diminished their educational attainment. There is evidence of high absen- teeism among asthmatic adults ${ }^{12}$ but no evidence that asthma in childhood actually reduces educational attainment. ${ }^{3-5}$ For their part, people with asthma may need to be more selective in the jobs they undertake to avoid occupations that provoke attacks. Jobs may be lost more easily or acquired less readily because of absence or diminished work performance due to illness. Certain jobs may themselves provoke asthma in otherwise healthy individuals, though "occupational asthma" seems to be relatively uncommon. ${ }^{6}$

There have been no controlled prospective studies of the influence of asthma on employment. One uncontrolled study found that, at the age of $21,22 \%$ of those with current frequent symptoms said that asthma had had a considerable influence on their choice of occupation, and $25 \%$ said that prospective employers had been influenced by their history of asthma. ${ }^{5}$ There are no reports of the impact of asthma on unemployment, frequency of job changes, promotion prospects, or retirement due to illness.

We report here the relation between employment history at age 23 years and a history of asthma or wheezing illness. The data are from the National Child Development Study, which is a cohort study of all children who were born in England, Scotland, and Wales in one week in March 1958. The database offers a good opportunity to explore prospectively the influence of asthma on employment in young adults.

\section{Methods}

Information about a wide range of medical, social, educational, and employment variables was collected by trained interviewers at four ages $(7,11,16$, and 23 years) for the original cohort of 17319 births included in the National Child Development Study.

\section{THE QUESTIONS ON ASTHMA}

The form of the questions on asthma and wheezing illness was different at each age.

At age 7, parents were asked whether the child had ever had "attacks of asthma", and the same question was repeated for "attacks of bronchitis with wheezing"; if the reply to either question was positive the number of attacks in the past 12 months was recorded.

At age 11, parents were asked whether the child had ever had attacks of "asthrna," "wheezing bronchitis," or neither of these. If attacks had occurred in the past 12 months, their frequency was categorised as
Medical School,

Reprint requests to:

Dr Sibbald

Accepted 22 August 1991 
"at least once a week," "usually less than once a week but can expect one a month," "at least one attack in the past year but less frequently than once a month," or "had attacks in the past year but don't know how frequently."

At age 16, parents were asked whether the child "ever had an attack of asthma or wheezy bronchitis." If attacks had occurred in the past 12 months, their frequency was categorised as "at least once a week," "usually less than once a week but at least once a month," "less than once a month, frequency unknown."

At age 23, subjects were asked "Since your 16 th birthday have you had an attack of asthma or wheezy bronchitis?" If the response was positive they were asked whether attacks had occurred in the past 12 months, whether prescribed medicines were used to control these attacks, and whether they were currently under medical supervision for attacks.

\section{ASTHMA GROUPS}

Because at ages 16 and 23 no distinction was made between asthma and wheezing, and because there are no good clinical or pathological grounds for distinguishing between them $^{78}$ the two entities have been combined and are referred to throughout this paper as asthma. Subjects were further grouped as follows: (1) current asthma-defined as asthma or wheeze within the past 12 months at age 23; (2) past asthma-defined as asthma or wheeze reported at age $7,11,16$, or 23 , but no asthma or wheeze within the past 12 months at age 23; (3) never asthma-defined as no reported asthma or wheeze at ages $7,11,16$ or 23 . A fourth group of subjects had no reported history of asthma or wheeze, but as data were missing for one or more interviews they could not be classified with certainty and so were excluded from analysis.

The linked database, comprising only those subjects who had completed all interviews, was used as a starting point for this analysis. Subjects with incomplete records who reported asthma or wheeze at age 23 years were added to the group with current asthma if symptoms had occurred within the previous 12 months or to the group with past asthma if symptoms had last occurred more than a year previously. Subjects with incomplete records who reported no history of asthma or wheeze at age 23 years but had reported asthma or wheeze at 7,11 , or 16 years were also assigned to the group with past asthma. This allowed us to make maximum use of the available data.

On the basis of the reported frequency of attacks in the past 12 months at ages 7 and 11 , asthma was further classified as severe (in those who had had five or more attacks in the past year at age 7 or attacks occurring at least once a month at age 11) or mild (in the remainder).

\section{EMPLOYMENT}

We wished to examine the possibilities that persons with past or current asthma were more likely to have been unemployed; took longer to find their first job; changed jobs more frequen- tly; had more periods out of the labour force, as a result of illness in particular; or had attained a lower social group. From the data available on subjects' employment history we selected the following variables: current employment status, number of jobs ever held, months employed as a proportion of the time since leaving school, current social position, months in current or last full time job. The measures of unemployment examined included whether ever unemployed, number of periods of unemployment, months unemployed as a proportion of the time since leaving school, number of months unemployed before first job. Time spent out of the labour force was described in terms of whether the subject was ever out of the labour force, months out of the labour force as a proportion of the time since leaving school, whether having a long term illness was the reason for any period out of the labour force.

\section{ANALYSIS}

Men and women were analysed separately because of their very different employment histories. The findings in subjects with no history of asthma were compared with those who had "current asthma" and those who had had "past asthma." The findings are expressed as odds ratios or differences in means, as appropriate. The $95 \%$ confidence interval $(95 \% \mathrm{CI})$ is given for each estimate.

A logistic regression model was fitted to examine the associations between asthma and selected employment and unemployment variables while potential confounding effects, such as sex, region of birth, maximum educational qualification attained, and father's social class, were controlled for. The odds of employment and unemployment are given together with the $95 \%$ confidence intervals (95\% CI).

\section{Results}

RESPONSE RATES

Of the 17319 subjects in the original cohort, $12534(72 \%)$ were interviewed at age 23 years. Of those interviewed, $460(4 \%)$ had current asthma. Of these, $192(42 \%)$ were male; 2758 $(22 \%)$ had had past asthma, of whom 1522 $(55 \%)$ were male; and $5161(41 \%)$ had never had asthma, of whom 2505 (49\%) were male. The remaining 4155 subjects had no reported history of asthma, but as data for one or more interviews were missing they are excluded from this analysis.

\section{CURRENT ASTHMA AND EMPLOYMENT}

At age 23 years men with current asthma were less likely to be employed and more likely to be out of the labour force than men who had never had asthma. Women with current asthma were more likely to be unemployed than women who had never had asthma. The differences reached significance only for the proportion of men out of the labour force (table 1).

Both men and women with current asthma tended to have a worse employment history than did those who had never had asthma (tables 2-3). Men with current asthma tended to have had more jobs, spent less time in 
Table 1 Employment status at age 23 years by sex and history of asthma

\begin{tabular}{|c|c|c|c|c|}
\hline \multirow[b]{2}{*}{ Current employment status } & \multicolumn{3}{|c|}{ History of asthma (No (\%)) } & \multirow{2}{*}{$\begin{array}{l}\text { Difference compared with } \\
\text { "never asthma" } \\
\text { Odds ratio }(95 \% \text { CI) }\end{array}$} \\
\hline & Current & Past & Never & \\
\hline \multicolumn{5}{|l|}{ MEN } \\
\hline Total & $192(100)$ & $1522(100)$ & $2505(100)$ & \multirow{4}{*}{$\begin{array}{l}\text { Current } 0.96(0.83 \text { to } 1.12) \\
\text { Past } 0.99(0.95 \text { to } 1.03) \\
\text { Current } 0.90(0.56 \text { to } 1.44) \\
\text { Past } 1.18(0.99 \text { to } 1.41) \\
\text { Current } 2.53(1.06 \text { to } 6.04) \\
\text { Past } 1.33(0.79 \text { to } 2.24)\end{array}$} \\
\hline Employed & $155(81)$ & $1259(83)$ & $2102(84)$ & \\
\hline Unemployed & $18(9)$ & $188(12)$ & $262(10)$ & \\
\hline Out of labour force & $6(3)$ & $25(2)$ & $31(1)$ & \\
\hline \multicolumn{5}{|l|}{ WOMEN } \\
\hline Total & $268(100)$ & $1236(100)$ & $2656(100)$ & \multirow{4}{*}{$\begin{array}{l}\text { Current } 1.01(0.88 \text { to } 1.17) \\
\text { Past } 0.92(0.86 \text { to } 0.98) \\
\text { Current } 1.44(0.91 \text { to } 2.26) \\
\text { Past } 1.59(1.24 \text { to } 2.02) \\
\text { Current } 0.87(0.68 \text { to } 1.12) \\
\text { Past } 1.06(0.95 \text { to } 1.19)\end{array}$} \\
\hline Employed & $181(68)$ & $760(61)$ & $1771(67)$ & \\
\hline Unemployed & $21(8)$ & $107(9)$ & $145(5)$ & \\
\hline Out of labour force & $63(24)$ & $354(29)$ & $717(27)$ & \\
\hline
\end{tabular}

Table 2 Employment history by history of asthma in men

\begin{tabular}{|c|c|c|c|c|c|c|c|}
\hline & \multicolumn{6}{|c|}{ History of asthma } & \multirow{3}{*}{$\begin{array}{l}\text { Difference compared with } \\
\text { "never asthma" } \\
\text { (Mean difference (DM) (95\% CI) } \\
\text { or odds ratio (OR) (95\% CI) }\end{array}$} \\
\hline & \multicolumn{2}{|l|}{ Current } & \multicolumn{2}{|l|}{ Past } & \multicolumn{2}{|l|}{ Never } & \\
\hline & Value & Sample size & Value & Sample size & Value & Sample size & \\
\hline If ever employed, mean No of jobs & $2 \cdot 94$ & 187 & 2.98 & 1493 & $2 \cdot 75$ & 2446 & $\begin{array}{l}\text { Current } \mathrm{DM}=0.19(-9.80 \text { to } 0.48) \\
\text { Past } \quad \mathrm{DM}=0.23(0.11 \text { to } 0.35)\end{array}$ \\
\hline $\begin{array}{l}\text { Mean \% months employed since } \\
\text { leaving school }\end{array}$ & $84 \cdot 3$ & 178 & $87 \cdot 0$ & 1463 & $88 \cdot 0$ & 2424 & $\begin{array}{l}\text { Current } D M=-3.7(-7.5 \text { to } 6.3) \\
\text { Past DM }=-1.0(-2.4 \text { to } 0.4)\end{array}$ \\
\hline $\begin{array}{l}\text { Current job social group: } \\
\text { No }(\%) \text { in groups } 1-3\end{array}$ & $67(36)$ & 185 & $538(37)$ & 1445 & $971(41)$ & 2369 & $\begin{array}{l}\text { Current } O R=0.88(0.69 \text { to } 1.12) \\
\text { Past OR }=0.91(0.83 \text { to } 0.99)\end{array}$ \\
\hline $\begin{array}{l}\text { Mean No of months in } \\
\text { current full time job }\end{array}$ & $37 \cdot 0$ & 151 & $39 \cdot 8$ & 1288 & $41 \cdot 6$ & 2054 & $\begin{array}{l}\text { Current } D M=-4.6(-9.6 \text { to } 0.4) \\
\text { Past DM }=-1.8(-3.9 \text { to } 0.3)\end{array}$ \\
\hline
\end{tabular}

Table 3 Employment history by history of asthma in women

\begin{tabular}{|c|c|c|c|c|c|c|c|}
\hline & \multicolumn{6}{|c|}{ History of asthma } & \multirow{3}{*}{$\begin{array}{l}\text { Difference compared with } \\
\text { "never asthma" } \\
\text { (Mean difference (DM) (95\% CI) } \\
\text { or odds ratio (OR) (95\% CI) }\end{array}$} \\
\hline & \multicolumn{2}{|l|}{ Current } & \multicolumn{2}{|l|}{ Past } & \multicolumn{2}{|l|}{ Never } & \\
\hline & Value & Sample size & Value & Sample size & Value & Sample size & \\
\hline If ever employed, mean No of jobs & 2.99 & 263 & $2 \cdot 72$ & 1210 & $2 \cdot 69$ & 2607 & $\begin{array}{l}\text { Current } \mathrm{DM}=0.30(0.60 \text { to } 0.54) \\
\text { Past } \quad \mathrm{DM}=0.03(-8.84 \text { to } 0.15)\end{array}$ \\
\hline $\begin{array}{l}\text { Mean \% of months employed since } \\
\text { leaving school }\end{array}$ & $76 \cdot 5$ & 249 & $74 \cdot 4$ & 1178 & $78 \cdot 4$ & 2535 & $\begin{array}{l}\text { Current DM }=-1.9(-5.5 \text { to } 1.7) \\
\text { Past DM }=-4.0(-5.9 \text { to }-2.1)\end{array}$ \\
\hline $\begin{array}{l}\text { Current job social group: } \\
\text { No }(\%) \text { in groups } 1-3\end{array}$ & $171(66)$ & 258 & $810(68)$ & 1200 & $1864(72)$ & 2589 & $\begin{array}{l}\text { Current } O R=0.92(0.79 \text { to } 1.07) \\
\text { Past OR }=0.94(0.88 \text { to } 1.00)\end{array}$ \\
\hline $\begin{array}{l}\text { Mean No of months in } \\
\text { current full time job }\end{array}$ & 35.9 & 157 & 39.9 & 660 & $40 \cdot 2$ & 1582 & $\begin{array}{l}\text { Current } \mathrm{DM}=-4.3(-8.8 \text { to } 0.2) \\
\text { Past } \quad \mathrm{DM}=-0.3(-2.9 \text { to } 2.3)\end{array}$ \\
\hline
\end{tabular}

employment since leaving school, attained a lower social group at age 23 years, and spent less time in their current full time job than men who had never had asthma (table 2). The findings in women were similar (table 3 ). The differences reached significance only for the proportion of time spent in employment since leaving school among men and the proportion of women in the upper social groups at age 23 years.

Men with current asthma were more likely to have ever been unemployed, had had more periods of unemployment, had spent more time unemployed since leaving school, and had had a longer period of unemployment before starting their first job than men who had never had asthma (table 4). The findings were similar for women (table 5). The differences reached significance only for the proportions of men and women who had ever been unemployed.

Men with current asthma had spent more time out of the labour force since leaving school than men who had never had asthma and were more likely to have given long term illness as their reason for this absence (table 6). The findings were similar for women. The differences were small and did not reach statistical significance. 
Table 4 Unemployment history by history of asthma in men

\begin{tabular}{|c|c|c|c|c|c|c|c|}
\hline & \multicolumn{6}{|c|}{ History of asthma } & \multirow{3}{*}{$\begin{array}{l}\text { Difference compared with } \\
\text { " never asthma" } \\
\text { (Mean difference (DM) (95\% CI) } \\
\text { or odds ratio (OR) (95\% CI) }\end{array}$} \\
\hline & \multicolumn{2}{|l|}{ Current } & \multicolumn{2}{|l|}{ Past } & \multicolumn{2}{|l|}{ Never } & \\
\hline & Value & Sample size & Value & Sample size & Value & Sample size & \\
\hline No (\%) ever unemployed & $103(54)$ & 192 & 739 (49) & 1522 & $1104(44)$ & 2505 & $\begin{array}{l}\text { Current OR }=1.22(1.00 \text { to } 1.48) \\
\text { Past OR }=1.10(1.02 \text { to } 1.19)\end{array}$ \\
\hline $\begin{array}{l}\text { If ever unemployed, mean number } \\
\text { of periods unemployed }\end{array}$ & $2 \cdot 0$ & 103 & 1.9 & 739 & $1 \cdot 8$ & 1104 & $\begin{array}{l}\text { Current } \begin{array}{l}\mathrm{DM} \\
\text { Past }\end{array} \quad \mathrm{DM}=0.2(-0.1 \text { to } 0.5) \\
=0.1(-1.8 \text { to } 0.2)\end{array}$ \\
\hline $\begin{array}{l}\text { Mean \% of months unemployed } \\
\text { since leaving school }\end{array}$ & $7 \cdot 8$ & 192 & $7 \cdot 2$ & 1522 & $6 \cdot 2$ & 2505 & $\begin{array}{l}\text { Current } \mathrm{DM}=1.6(-0.8 \text { to } 4.0) \\
\text { Past } \quad \mathrm{DM}=0.1(-0.0 \text { to } 2.0)\end{array}$ \\
\hline $\begin{array}{l}\text { Mean number of months } \\
\text { unemployed before first job }\end{array}$ & 0.5 & 187 & $0 \cdot 7$ & 1492 & $0 \cdot 6$ & 2446 & $\begin{array}{l}\text { Current DM }=-0.0(-0.3 \text { to } 0.2) \\
\text { Past DM }=0.1(-0.3 \text { to } 0.3)\end{array}$ \\
\hline
\end{tabular}

Table 5 Unemployment history by history of asthma in women

\begin{tabular}{|c|c|c|c|c|c|c|c|}
\hline & \multicolumn{6}{|c|}{ History of asthma } & \multirow{3}{*}{$\begin{array}{l}\text { Difference compared with } \\
\text { "never asthma" } \\
\text { (Mean difference (DM) (95\% CI) } \\
\text { or odds ratio (OR) (95\% CI) }\end{array}$} \\
\hline & \multicolumn{2}{|l|}{ Current } & \multicolumn{2}{|l|}{ Past } & \multicolumn{2}{|l|}{ Never } & \\
\hline & Value & Sample size & Value & Sample size & Value & Sample size & \\
\hline No (\%) ever unemployed & $129(48)$ & 268 & $551(45)$ & 1236 & $1064(40)$ & 2656 & $\begin{array}{l}\text { Current OR }=1.20(1.10 \text { to } 1.43) \\
\text { Past OR }=1.11(1.02 \text { to } 1.21)\end{array}$ \\
\hline $\begin{array}{l}\text { If ever unemployed, mean number } \\
\text { of periods unemployed }\end{array}$ & $1 \cdot 7$ & 129 & $1 \cdot 6$ & 551 & $1 \cdot 6$ & 1064 & 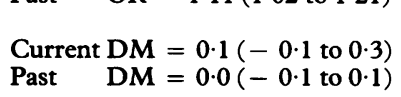 \\
\hline $\begin{array}{l}\text { Mean \% of months unemployed } \\
\text { since leaving school }\end{array}$ & $6 \cdot 2$ & 268 & $5 \cdot 7$ & 1236 & $4 \cdot 8$ & 2656 & $\begin{array}{l}\text { Current } \mathrm{DM}=1.4(-1.3 \text { to } 3.1) \\
\text { Past } \quad \mathrm{DM}=0.9(0.1 \text { to } 1.7)\end{array}$ \\
\hline $\begin{array}{l}\text { Mean number of months } \\
\text { unemployed before first job }\end{array}$ & 0.5 & 262 & $0 \cdot 6$ & 1209 & $0 \cdot 5$ & 2605 & 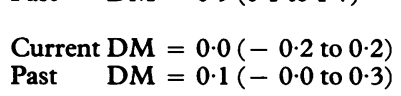 \\
\hline
\end{tabular}

Table 6 "Out of labour force" history by sex and history of asthma

\begin{tabular}{|c|c|c|c|c|c|c|c|}
\hline & \multicolumn{6}{|c|}{ History of asthma } & \multirow{3}{*}{$\begin{array}{l}\text { Difference compared with } \\
\text { "never asthma" } \\
\text { (Mean difference (DM) (95\% CI } \\
\text { or odds ratio (OR) (95\% CI) }\end{array}$} \\
\hline & \multicolumn{2}{|l|}{ Current } & \multicolumn{2}{|l|}{ Past } & \multicolumn{2}{|l|}{ Never } & \\
\hline & Value & Sample size & Value & Sample size & Value & Sample size & \\
\hline \multicolumn{8}{|l|}{ MEN } \\
\hline No $(\%)$ ever out of labour force & $58(30)$ & 192 & $424(28)$ & 1522 & \multicolumn{2}{|c|}{$743(30) 2505$} & $\begin{array}{l}\text { Current OR }=1.02(0.78 \text { to } 1.32) \\
\text { Past OR }=0.94(0.85 \text { to } 1.04)\end{array}$ \\
\hline $\begin{array}{l}\text { Mean } \% \text { of months out of labour } \\
\text { force since leaving school }\end{array}$ & $5 \cdot 0$ & 187 & 2.9 & 1511 & $2 \cdot 8$ & 2477 & \multirow{2}{*}{$\begin{array}{l}\text { Current DM }=2.2(-0.4 \text { to } 4.8) \\
\text { Past DM }=0.1(-0.6 \text { to } 0.8) \\
\text { Current } O R=2.01(0.96 \text { to } 4.22) \\
\text { Past OR }=1.55(1.05 \text { to } 2 \cdot 28)\end{array}$} \\
\hline No $(\%)$ ever long term sick & $8(4)$ & 192 & $49(3)$ & 1522 & $52(2)$ & 2505 & \\
\hline $\begin{array}{l}\text { WOMEN } \\
\text { No }(\%) \text { ever out of labour force }\end{array}$ & $154(58)$ & 268 & $723(59)$ & 1236 & $1539(58)$ & 2656 & $\begin{array}{l}\text { Current OR }=0.99(0.85 \text { to } 1.16) \\
\text { Past OR }=1.10(0.94 \text { to } 1.08)\end{array}$ \\
\hline $\begin{array}{l}\text { Mean } \% \text { of months out of labour } \\
\text { force since leaving school }\end{array}$ & $16 \cdot 3$ & 263 & $17 \cdot 4$ & 1231 & $14 \cdot 4$ & 2640 & \multirow{2}{*}{$\begin{array}{l}\text { Current } \mathrm{DM}=1.9(-1.4 \text { to } 5.2) \\
\text { Past } \mathrm{DM}=3.0(1.3 \text { to } 4.7) \\
\text { Current } \mathrm{OR}=1.44(0.69 \text { to } 3.02) \\
\text { Past } \quad \mathrm{OR}=1.76(1.19 \text { to } 2.60)\end{array}$} \\
\hline No (\%) ever long term sick & $8(3)$ & 268 & $45(4)$ & 1236 & $55(2)$ & 2656 & \\
\hline
\end{tabular}

PAST ASTHMA AND EMPLOYMENT

At age 23 years men with past asthma were less likely to be employed, more likely to be unemployed, and more likely to be out of the labour force than were men who had never had asthma (table 1). The findings for women were similar (table 1). The differences reached significance only for the proportion of women unemployed.

Men with past asthma tended to have had more jobs, spent less time in employment since leaving school, attained a lower social group at age 23 years, and spent less time in their current full time job than men who had never had asthma (table 2). The differences reached significance for the mean number of jobs and the proportion in upper social groups at age 23 years. The findings for women were similar to those for men, though none of the differences reached statistical significance (table 3 ).

Men with past asthma were more likely to 
have ever been unemployed, had had more periods of unemployment, and had spent more time unemployed since leaving school than men who had never had asthma (table 4). The differences reached significance only for the proportion who had ever been unemployed. Women with past asthma were significantly more likely to have ever been unemployed and had spent significantly more time unemployed since leaving school than women who had never had asthma (table 5).

Men with past asthma were significantly more likely than men who had never had asthma to have given long term illness as their reason for being out of the labour force (table 6). Women with past asthma had spent significantly more time out of the labour force since leaving school and were significantly more likely to have given long term illness as their reason for this absence than were women who had never had asthma (table 6).

\section{CONFOUNDING EFFECTS}

Subjects' history of asthma and their history of employment might both be influenced by their region of birth, maximum educational qualification attained, and father's social class. We therefore fitted a logistic regression model to examine the association between asthma and whether subjects had ever been employed or unemployed while controlling for these potential confounding effects. The findings showed that the risk of unemployment was higher for subjects with a current history of asthma (odds ratio $1.32,95 \%$ CI $1.09-1 \cdot 61$ ) or a past history of asthma (odds ratio $1 \cdot 54,95 \%$ CI $1 \cdot 27-1 \cdot 85$ ) than for those with no history of asthma. There was no significant association between a history of asthma and ever being employed.

We fitted a second logistic regression model to examine the association between the severity of asthma and whether subjects had ever been employed or unemployed while controlling for the potential confounding effects of sex, region of birth, maximum educational qualification attained, and father's social class. Of the $\mathbf{3 2 1 8}$ subjects with current or past asthma, there were 166 who fulfilled the criteria for severe asthma and 3052 designated as having mild asthma. By comparison with subjects who had never had asthma, the risk of ever being unemployed was slightly higher among those with severe asthma (odds ratio $1 \cdot 18,95 \%$ CI $0.82-1.68$ ) than among those with mild asthma (odds ratio $1 \cdot 15,95 \%$ CI $1 \cdot 05-1 \cdot 26$ ), though in both instances the additional risk was small. No significant association was found between the severity of asthma and ever being employed.

\section{Discussion}

The findings suggest that asthma and wheezing illness have a small adverse affect on employment in young adults of both sexes. When compared with subjects without asthma, 23 year old men and women with a current or past history of asthma or wheezing illness were more likely to have been unemployed, had spent less time in employment, had had more jobs, and had spent less time in their most recent full time jobs. One reason for this may be that young people with asthma need to change jobs more frequently to find work that does not aggravate their asthma. Alternatively, jobs may be lost more readily or acquired less easily (or both) because of absence due to illness.

The risk of unemployment tended to be higher among subjects with "severe" asthma than among those whose asthma had always been mild. This difference was small and not statistically significant. A larger study would be needed to determine whether there is a true association. Our index of severity was crude, being based on a report of frequent asthmatic symptoms at any one of four interviews during the subjects' life, and may therefore have obscured a true relationship.

The impact of asthma on employment was evident in subjects with past asthma as well as in those with current asthma. Other studies based on data from the National Child Development Study have shown that childhood or adolescent ill health, including asthma, is associated with increased ill health ${ }^{9}$ and lower social class ${ }^{10}$ at age 23 years, though in both instances other factors were thought to be more important determinants of people's health and social status at the age of 23 than childhood health. In our study subjects with past asthma had a significantly lower social class grouping (on the basis of their current job) at 23. These findings raise the possibility that people with past asthma enjoy less good health at 23 , which in turn adversely affects employment opportunities and hence the social class grouping attained by the age of 23 . Another possibility is that employers may associate childhood asthma with emotional problems and diminished academic achievement and so discriminate against those with a past history of asthma. The data do not allow us to distinguish between the possibility of prejudice against people who have been labelled asthmatic and the possibility that asthma actually interferes with education, job training, or work performance.

The age at onset and the duration of asthma are potentially important factors influencing employment at the age of 23 . The subjects with current asthma were too few, however, and too many data on those with past asthma were missing to support an analysis of employment history by age at onset and duration of asthma.

Other methodological limitations of the study need to be considered. Data on nonresponse have been analysed for the possibility of bias and reported elsewhere. ${ }^{11}$ The main response bias has been that children with indicators of "disadvantage" are underrepresented, though this has not exceeded $10 \%$ for any particular index. If, as discussed above, asthma does predispose to attainment of a lower social class, then this selective non-response may have led to an underestimation in this study of the true impact of asthma on employment. Similar arguments would apply to the exclusion from this analysis of the $24 \%$ of 23 year olds who had no reported history of asthma or wheezing illness, but for whom data were missing at one or more interviews.

The National Child Development Study was 
not set up primarily to examine asthma so its method of identification has differed slightly from interview to interview. This is unlikely to have influenced results because the essential questionnaire elements of wheezing and diagnosed asthma were both assessed at each interview, as was their occurrence over the past 12 months, a conventional period for describing "current" asthma. The prevalence estimates of asthma based on the linked and unlinked National Child Development Study database are similar to those found elsewhere. ${ }^{12}$

The smallness of the negative impact of asthma on employment should reassure parents who are concerned about the job prospects of their asthmatic children. There is at present no published evidence that asthma adversely affects educational achievement or job training, or that work performance is impaired among those who are employed. Indeed, present evidence suggests that on average educational attainment is as good as or better than that of people without asthma. ${ }^{3-5}$ For people with asthma as a group therefore both education and employment seem likely to be little affected.
1 Sibbald B. Patient self-care in acute asthma. Thorax 1989;44:97-101.

2 White PT, Pharoah CA, Anderson HR, Freeling P. Randomized controlled trial of small group education on the outcome of chronic asthma in general practice. $J R$ Coll Gen Pract 1989;39:182-6.

3 Mitchell RG, Dawson B. Educational and social characteristics of children with asthma. Arch Dis Child 1973;48: 467-71.

4 Peckham C, Butler N. A national study of asthma in childhood. J Epidemiol Community Health 1978;32:79-85. 5 Martin AJ, Landau LI, Phelan PD. Asthma from childhood at age 21: the patient and his disease. BMJ 1982;284: $380-2$.

6 Davies RJ, Blainey AA. Occupational asthma. In: Clark TJH, Godfrey S, eds. Asthma. 2nd ed. London: Chapman and Hall, 1983:202-3.

7 Williams H, McNicol KN. Prevalence, natural history, and relationship of wheezy bronchitis and asthma in children. An epidemiological study. $B M J 1969$;iv:321-5.

8 Sibbald B, Horn MEC, Gregg I. A family study of the genetic basis of asthma and wheezy bronchitis in children. Arch Dis Child 1980;55:354-7.

9 Power C, Peckham C. Childhood morbidity and adulthood ill health. J Epidemiol Community Health 1990;44:69-74.

10 Power C, Manor O, Fox AJ, Fogelman K. Health in childhood and social inequalities in health in young adults. Journal of the Royal Statistical Society 1990;153 Journal of the

11 Fogelman K, ed. Growing up in Great Britain : papers from the National Child Development Study. London: National Children's Bureau Series, 1983.

12 Anderson HR, Bland JM, Patel S, Peckham C. The natural history of asthma in childhood. $J$ Epidemiol Community Health 1986;40:121-9. 